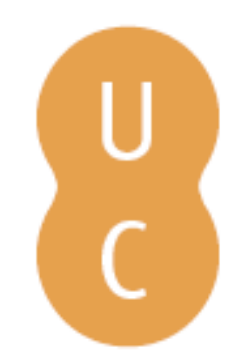

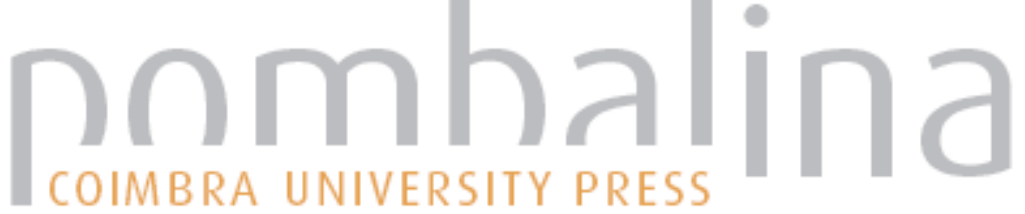

\section{Transatlantic Sapphos}

\author{
Autor(es): DuBois, Page
}

Publicado por: Imprensa da Universidade de Coimbra

URL

persistente: URI:http://hdl.handle.net/10316.2/42347

DOI: $\quad$ DOI:https://doi.org./10.14195/978-989-26-1308-6_35

Accessed : $\quad$ 26-Apr-2023 13:57:00

A navegação consulta e descarregamento dos títulos inseridos nas Bibliotecas Digitais UC Digitalis, UC Pombalina e UC Impactum, pressupõem a aceitação plena e sem reservas dos Termos e Condições de Uso destas Bibliotecas Digitais, disponíveis em https://digitalis.uc.pt/pt-pt/termos.

Conforme exposto nos referidos Termos e Condições de Uso, o descarregamento de títulos de acesso restrito requer uma licença válida de autorização devendo o utilizador aceder ao(s) documento(s) a partir de um endereço de IP da instituição detentora da supramencionada licença.

Ao utilizador é apenas permitido o descarregamento para uso pessoal, pelo que o emprego do(s) título(s) descarregado(s) para outro fim, designadamente comercial, carece de autorização do respetivo autor ou editor da obra.

Na medida em que todas as obras da UC Digitalis se encontram protegidas pelo Código do Direito de Autor e Direitos Conexos e demais legislação aplicável, toda a cópia, parcial ou total, deste documento, nos casos em que é legalmente admitida, deverá conter ou fazer-se acompanhar por este aviso.

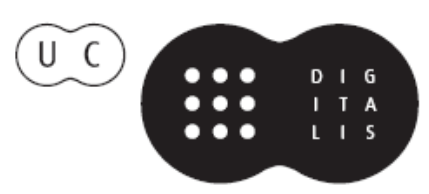





\section{TRANSATLANTIC SAPPHOS}

Page duBois

Resumo: Este ensaio tenta desenhar um mapa do legado lírico da poeta Safo nas obras das mulheres poetas do século XX (dentro, mas também além do mundo anglófono). Demonstra-se como a própria receção transformou o nosso entendimento da antiguidade e, nomeadamente, como o interesse pela sexualidade e a negociação exigida pelas dificuldades do amor entre duas pessoas do mesmo sexo nas sociedades contemporâneas transformou a nossa leitura daquele período, bem como das suas obras de arte.

Palavras-chave: Safo; poesia; mulheres; sexualidade; negociação; receção.

Abstract: This essay aims at drawing a map of the legacy of the archaic Greek lyric poet Sappho on twentieth-century women's writing (within, but also beyond, the Anglophone world). It shows how reception itself transforms our understanding of antiquity, namely how the interest in sexuality and the demanding for the negotiation of the difficulties of same-sex love in contemporary societies transformed readings of ancient societies and their works of art. 
Keywords: Sappho; poetry; women; sexuality; negotiation; reception.

"Reception" in classical studies has come to mean not only the ways in which an ancient work of art was "received" in a later period, how it was transmitted, what effects it had on that period, how it was understood, but also an examination of how the ways in which an ancient text, object, work of art, theory was received can transform our understanding of antiquity itself. ${ }^{1}$ In the twentieth century, for example, when scholars were affected by developments in the suffragist movement, the women's movement, in feminism, they looked at the women of antiquity in new ways, seeking out silent members of ancient communities, studying the ways in which gender relations worked in ancient societies, a topic that had been relatively neglected in earlier periods. The interest in sexuality, and in varieties of sexuality, that came to define a new field called the history of sexuality, also transformed readings of ancient societies and works of art. I am concerned here with the legacy of the archaic Greek lyric poet Sappho, who spent most of her life on the Eastern Mediterranean island of Lesbos, near the coast of what is now Turkey. Many of Sappho's verses, highly esteemed in antiquity, have been lost over the centuries, some only very recently discovered on fragments of ancient papyrus dug up from the sands of Egypt. The representation of Sappho, who writes often about her passion for other women, was transformed radically by the Roman poet Ovid, who in his Heroides spoke in her voice of her unrequited love for

1 This essay is based on a forthcoming book, Sappho: Understanding Classics, to be published in 2015 by I.B. Tauris (London). It is dedicated to Irene Ramalho Santos, with profound admiration, gratitude, and love. 
a man, Phaon, and of her imminent suicide. The understanding of Sappho in the post-Renaissance world was for a long time focused on her death, on the romance of her yearning for this man, and on the ways in which she stood for passionate and doomed eros rather than for "lesbianism." Sappho was seen not just as an exemplary female poet, but also and perhaps especially as a tragic figure. Visual artists represented Sappho, often with the male object of her unrequited love, Phaon, as in the work of the neo-classical painter David, who painted them together in 1809.

The American poet Hilda Doolittle (1886-1961), who published as H.D., was, among others, profoundly influenced by Sappho's fragments. As a young woman she met William Carlos Williams, Marianne Moore, and Ezra Pound, to whom she was briefly engaged. After moving to London, she came to know the imagist poets, and Pound championed her work. She had affairs with both women and men, and married the poet Richard Aldington; but her most enduring relationship was with Annie Winifred Ellerman, the English novelist known as "Bryher," whose father, a shipowner and financier who at the time of his death in 1933 was said to be the richest Englishman who had ever lived. Bryher was involved in film-making; her Pool group made Borderline in 1930, starring H.D. and the great African American singer and political activist Paul Robeson. Bryher, like H.D., married and had male lovers, but saw themselves as Lesbian lesbians as well; Bryher's memoir is entitled The Heart to Artemis. H.D.'s sensuous life was unconventional, full, complex, and polymorphous, marked by attachments to lovers of both genders, and by erotic suffering, it seems. H.D. was analyzed by Sigmund Freud, and later wrote of the experience in her Tribute to Freud. And while attracted to Japanese poetry, and the haiku, H.D. along with the other imagists early on began to derive inspiration from classical Greek poetry, and especially the archaic lyrics of Sappho. 
The most explicit acknowledgement of H.D.'s fascination with Sappho comes in the text entitled "The Wise Sappho," written in 1920 but published in 1982 by City Lights Books, from a manuscript in the Beinecke Rare Book and Manuscript Library at Yale University. H.D. begins this short essay by recalling the judgment of the Alexandrian poet Meleager, in "The Garland," where he weaves into his wreath of Sappho "few, but roses." Eileen Gregory discusses the essay in her book H.D. and Hellenism (1997), and remarks on the fact that H.D. does not cite the newer fragments of the poet, called the "Berlin fragments" and known to the poets of her day. She restricts her musings on Sappho to the fragments published by H. T. Wharton in 1885, and although Sappho seems to stand as a predecessor to H.D., she approaches her somewhat obliquely. She first takes issue with the Hellenistic poet's assessment, calling for not roses, but orange blossoms, "implacable flowerings made to seduce the sense when every other means has failed, poignard that glints, fresh sharpened steel. . ." (57). Sappho's words are for her "colours, or states. . . transcending colour yet containing. . . all colour" (58). Then they are rocks, or layers of rock. "Not flowers at all, but an island, a country, a continent, a planet, a world of emotion, differing entirely from any present day imaginable world of emotion. .." (58). H.D. invokes an embodied woman, ironic, aristocratic, intolerant, mocking the country girl. "Her bitterness was on the whole the bitterness of the sweat of Eros" (59).

H.D.'s Sappho is not the worshiper of the Olympian gods, but the petulant, nervous Sappho, lashing out at her companions. She stands in the wind from Asia, in a Western gale. H.D. admires her poetic craft, sees her "artistic wisdom," but questions her emotional, personal wisdom, finding immoderation and inconstancy in love in her poetry. She had "the wisdom of simplicity, the blindness of genius" (65). H.D. calls up her child, Cleis, and her beloved girls, made vivid through H.D.'s prose: 
angry Eranna who refused everyone and bound white violets only for the straight hair she herself braided with precision and cruel self-torturing neatness about her own head. We know of Gorgo, over-riotous, too heavy, with special intoxicating sweetness, but exhausting, a girl to weary of, no companion, her over-soft curves presaging early development of heavy womanhood. (67)

H.D. is there, on Lesbos, with these woman, imagining them fully, projecting from the few words of Sappho's fragment a dense, corporeal reality for these names. She cites the living and the dead, and ends with "Rhodope," the beauty married by Sappho's brother. So H.D. returns to "roses," to the rosy-faced "Graeco-Egyptian beauty" of Naucratis. In the end, H.D. turns back on her rejection of Meleager's characterization of his predecessor, writing "Little - not little - but all, all roses!" She is "the pseudonym for poignant human feeling," "the rocks set in a blue sea, the sea itself, breaking and tortured and torturing, but never broken" (67). H.D. remembers all those ancient writers who read her, admired her wisdom - Plato, Meleager, the tragic poet Sophocles, "The Roman Emperor" who saw life as worth living if he could hear Sappho's songs, Catullus, until the Vatican saw her as a rival to their own "Poet," and destroyed her poems. She imagines, finally, scholars, hectic antiquaries, searching for "a precious palimpsest among the funereal glories of the sand-strewn Pharaohs" (69). H.D.'s own epitaph, inscribed on her grave in the family plot in Pennsylvania, reveals her debt to Sappho:

So you may say,

Greek flower; Greek ecstasy

reclaims forever

one who died

following intricate song's

lost measure. 
H.D. may have lacked the ecstatic identification with the ancient Lesbian poet that some feminists, lesbians, and women poets felt, but her poetics, her sense of Sappho as tortured, ironic, and not broken, persist in her verse and prose.

The American feminist and lesbian poet Judy Grahn published a set of essays called The Highest Apple, in 1985, invoking Sappho in her title. Part III of this text is entitled "To Surface With Lesbian Gods." She lists the many gods of Sappho's world, and continually refers to her present as she reads Sappho's fragments:

Perhaps, in fact, when Sappho speaks of the reddening sweet-apple at the topmost bough, the one that the apple-pickers could not reach - she is singing a womanly song of special protection for the essential female powers; they will never, quite, be reached, and taken from us. (93)

Grahn writes of the lost old gods, and "their possible reclamation in our modern Lesbian poetry" (93). She sees Lesbian feminism, and its female culture, as "straining to recoup its highest apple" (94). She reads the work of Emily Dickinson in this light: "her own love was primarily for women" (94). Amy Lowell, another American poet, is judged as not preoccupying herself "except indirectly with the re-establishment of the lost female godhead. . ." (100). But H.D. wrote the poem "Amaranth," which for Grahn "speaks in Sappho's voice directly to Aphrodite" (194). Audre Lorde reconnects with African divinities, African Amazon figures; Adrienne Rich names "the forces, the female godforces, and takes as her major subjects love and beauty, intelligence and memory - surely Aphrodite or perhaps the Hebrew Asherah - in another form" (116). Paula Gunn Allen draws on the traditions of indigenous American female creator gods. Grahn ends her essay on the power of female divinities to inspire her contemporaries, with a return to Sappho and her gods, 
and she cites in full David Campbell's 1982 prose version of Sappho's first poem: "Ornate-throned immortal Aphrodite. .." "Perhaps we are closer to recovering large portions of Sappho's world than we realize" (136).

The influence of Sappho on twentieth-century women's writing extended beyond the Anglophone world. Alejandra Pizarnik, born in Argentina in 1936, lived in exile in Paris and committed suicide in 1972. Her work explores eroticism, ecstasy, and depression, and her verses echo some of Sappho's themes, her forms of same-sex desire, and the fragmentary form in which we must read her poems. For example:

\author{
Lovers \\ a flower \\ not far from the night \\ my mute body \\ opens \\ to the delicate urgency of dew
}

or the poem translated as "Dawn":

Nude dreaming a solar night.

I have lain down animal days.

The wind and rain erased me

like a flame, like a poem

written on a wall.

These beautiful, anguished, sapphic poems, difficult to find in English, were translated by Frank Graziano, Maria Rosa Fort, and Suzanne Levine.

Cristina Peri Rossi, a Uruguayan writer born in 1941, was also exiled, and lives in Spain. Her novel Ship of Fools satirizes 
dictatorships, embraces feminism, and addresses pederasty. The book Evohé: poemas eroticos, published in Montevideo in 1971, takes its title, as she says, from "the onomatopoeic cry of the bacchantes during the feasts and rites paying homage to Bacchus, the god of revelry and wine." She uses the term, however, as "an amorous cry: the book proclaims love between two as a form of the Absolute as opposed to the orgy of multiple partners" (7). She also notes that when first published, Evohé "provoked a considerable scandal. Conditions at the time - just before the military dictatorship - were not favorable to poetry or to erotica. Later, EVOHE was banned entirely, along with the rest of my books" (8). Peri Rossi sets a fragment of Sappho as the epigrammatic prelude to her book: "Once again Eros, loosener of limbs, tortures me, sweet and bitter, invincible creature" (9). These poems of Peri Rossi were translated by Diana P. Decker:

\section{Dedication I}

I wrote her many poems

in fact, I even suffered a little for her.

I saw her the other day eating in a café

and the man with her

kept throwing breadcrumbs in her face.

I'll publish the poems any day now. (15)

I entered as if into a cathedral

and her legs vibrated

like the organ pipes

when, inside her,

I began to pronounce her,

to make music between the naves

under the acquiescent gaze

of all the illuminated virgins. (97) 
Marked by humor, defiance, and lesbian eros, Peri Rossi's verses constitute a brilliant, bravado "translation" of Sappho into another world.

These two women writers, poets of Latin America living in Europe, exemplify not only a complex trans-Atlanticism, but also a moving negotiation of the difficulties of same-sex love in contemporary societies, and the deployment of a rich legacy, excavated, rediscovered, inherited from the ancient Mediterranean.

\section{Works cited}

Bryher. The Heart to Artemis: A Writer's Memoirs. Ashfield, Massachusetts: Paris Press, 2006. Print.

Doolittle, Hilda (H.D.). Notes on Thought \& Vision and The Wise Sappho. San Francisco, California: City Lights Books, 1982. Print.

duBois, Page. Sappho is Burning. Chicago, Illinois: University of Chicago Press, 1987. Print.

Grahn, Judy. The Highest Apple: Sappho and the Lesbian Poetic Tradition. San Francisco, California: Spinsters, Ink, 1985. Print.

Graziano, Frank, ed. Alejandra Pizarnik: A Profile. Durango, Colorado: Logbridge-Rhodes, 1987. Print.

Greene, Ellen, ed. Re-Reading Sappho: Reception and Transmission. Berkeley, California: University of California Press, 1996. Print.

Gregory, Eileen. H.D. and Hellenism: Classic Lines. Cambridge: Cambridge University Press, 1997. Print.

Peri Rossi, Cristina. Evohé: poemas eroticos/Erotic Poems. Trans. Diana P. Decker. Washington, D.C.: Azul Editions, 1991 (Montevideo, Uruguay, 1971). Print. 